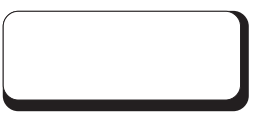

\title{
癌疼痛薬物治療の現状と最近の進歩
}

\author{
鈴木孝浩 \\ 日本大学医学部麻酔科学分野
}

\section{Present Status and Recent Advance of Pharmacotherapy in Cancer Pain Management}

\author{
Takahiro SuzUKI \\ Division of Anesthesiology, Nihon University School of Medicine
}

\begin{abstract}
Pain is one of the most common and intolerable cancer symptoms. It is therefore recommended that palliative care and pain management should be commenced even at the early stages of cancer. For most patients with cancer pain, the World Health Organization's three-step analgesic ladder can provide adequate pain relief. We need to fully understand how to use the analgesic ladder, how to select opioids, how to titrate the daily dose of analgesics, how to set the rescue doses for breakthrough pain, how to switch opioids when intolerable adverse events appear, how to treat opioid-insensitive pain, such as neuropathic and bone pain, and how to select patients that should be treated with neural blockade. This review focuses on the pharmacological agents currently available for effectively treating cancer pain.
\end{abstract}

Key words: cancer pain, WHO analgesics ladder, opioids, opioid rotation, neural blockade 癌疼痛, WHO 癌疼痛治療法, オピオイド, オピオイドローテーション, 神経ブロック

(J. Nihon Univ. Med. Ass., 2008; 67 (3): 160-166)

\section{はじめに}

過去の癌治療の概念として，初期には癌病変部位に対 する治療が優先され, 弚の間はたとえ痛みがあったとし ても，大げさに言えば非ステロイド系消炎鎮痛薬あるい はペンタゾシンなどの疼痛時使用で疼痛に対応していた と言っても過言ではなかった . 癌か診断された時点で既 に痛みを訴えている患者(約 $30 \%$ も存在する ${ }^{1)}$ にも関わ らず，光の時期には身体的疼痛だけではなく社会的，精 神的疼痛などを含めたトータルペイン (Fig. 1) として症 状緩和することは重要視されてこなかった . 癌の進行に 伴(疼痛は $70 \%$ 以上の症例を苦しめ 1 ), 癌浸潤による侵 害受容性疼痛や神経障害性疼痛だけでなく, 手術, 化学 療法, 放射線などの治療に伴う痛みや, 長期臥床に伴う 裖創, 便秘による腹痛, 倦怠感, 精神的苦痛による疼痛 増強が加わる.最近になり緩和医療の関わり方の概念が 変化し, 前述したように懸命な癌自体への治療が奏功せ ず，末期癌の状態になってから緩和医療を開始するので はなく, 癌治療の初期より疼痛を緩和する重要性か強調 されるようになってきている (Fig. 2) . 初期より疼痛コン トロールや精神的安定が得られることにより, 癌治療へ
の患者協力が得られやすくなり，治療成績も向上するこ とが期待されている.癌疼痛をトータルペインとして捉 え緩和医療を提供するためには，内科，外科的な全身状 態の管理を軸に，精神心理的サポート，疼痛コントロー ル, quality of life (QOL) の改善を包括的に行う必要があ る.本稿ではとくに現在の癌疼痛治療法や爫の進歩につ いて概説する．

\section{WHO 癌疼痛治療法}

1986 年に確立された WHO 癌疼痛治療ラダー (Fig. 3) に基づく疼痛管理により，癌患者の $80 \%$ 以上で良好な鎮 痛が得られることがわかっている2,3) . 鎮痛の第一目標は 痛みによる睡眠障害がないこと，次いで安静時痛がない こと，最終目標は体動時痛をコントロールすることにあ る . 疼痛管理を開始するに当たって，患者にもこの点を 理解させることが产の後の管理を円滑に進める上で重要 である.患者によっては数日毎に頻回に変わる薬量 , 即 座に鎮痛されない状況などに対して不満を抱きかねな い.ましてや副作用発症時には鎮痛薬による疼痛治療を 拒否する場合もある.よって鎮痛薬を少量から開始し， 鎮痛できる量まで徐々に増量し，同時に副作用対策も行 


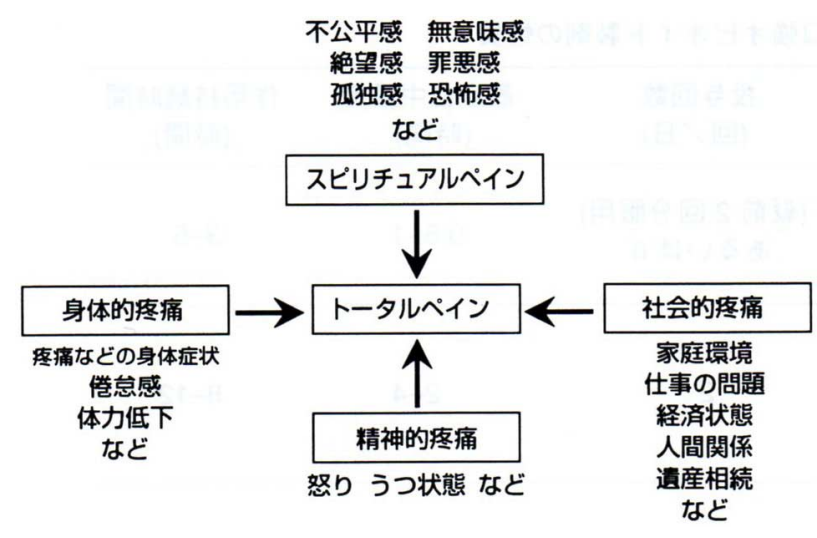

Fig. 1 トータルペインの概念

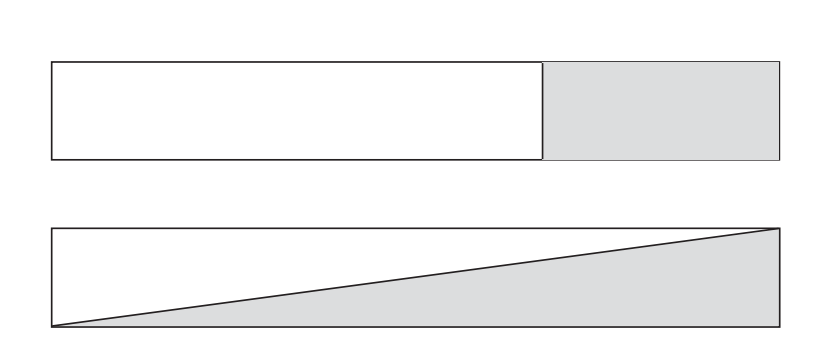

現在の概念

Fig. 2 癌疼痛治療のあり方

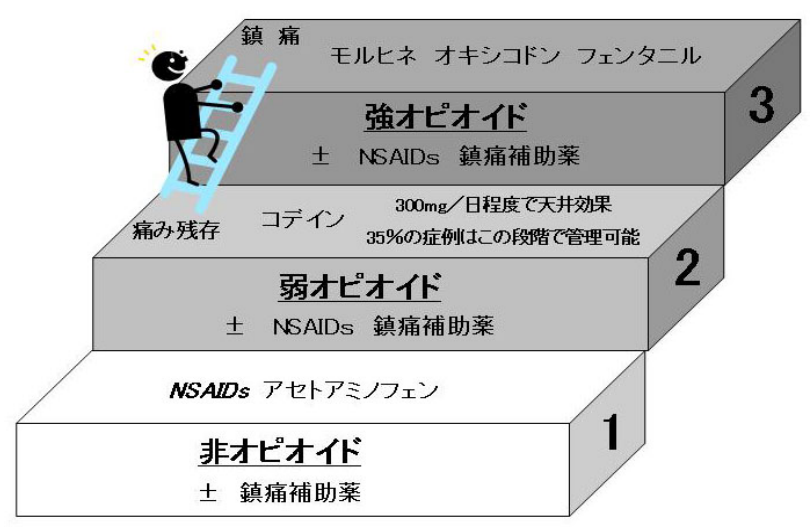

Fig. 3 WHO 癌疼痛治療ラダー

\section{うことを伝えておくべきである}

WHO 癌疼痛治療法の 5 原則はすでに医療関係者には 浸透しているものと思われるが, (1)経口的に (by mouth), (2)時刻を決めて規則正しく投与 (by the clock) , (3)除痛ラ ダーに乥って効力の順に (by the ladder), (4)患者ごとの 個別的な量で (for the individual), (5)产のうえで細かい配 慮を (attention to detail) となっている.ただし，オピオ イドの貼付斉等の開発により，経口製剂が第一選択とな らない症例も増加している. また本邦でも使用可能な強 オピオイドの種類か増えたことによって，効力順ではな く, 最初から第 3 段階薬より開始されるケースが多く なっている．もちろん疼痛か溞度であればこの対処は適
確であるが , 軽度の痛みの場合には副作用の少ない第 $1 ， 2$ 段階薬も有用である.なおさらのこと疼痛機序の診 断，弚れれの患者にあった個別治療，細かい配慮が必 要とされる.

1. 第 1 段階: 非ステロイド 系消炎鎮痛薬とアセトア ミノフェン

非ステロイド系消炎鎮痛薬 (NSAIDs) とアセトアミノ フェン(抗炎症作用は有さない) は軽度の痛みや骨性の痛 みには良い適応となる．また第 1 段階にて鎮痛不十分な 場合でも，中止することなく第 $2 ， 3$ 段階と併用するこ とにより, オピオイド投与量の減量やオピオイドによる 副作用の軽減につながる . 癌疼痛に対してどの系統の NSAIDs がより有効であるかは示されていないが，われ われは安全性と有効性に基づき一日量 2-4 g (4 回に分け て内服)のアセトアミノフェンを頻用している4) . シクロ オキシゲネース-2 (COX-2) 選択的阻害薬は心筋梗塞発症 率を増加させる可能性か指摘されており，循環器系既往 症に注意せねばならないが, 長期投与時にも消化器合併 症が少ない点で臨床的に使用しやすい．さらに基礎研究 領域では COX-2 選択的阻害薬のひとつであるセレコキ シブが本来の鎮痛作用以外にも腫瘍の増大や転移を減少 させる ${ }^{5)}$ と報告されており，臨床的な効果検証が期待さ れている。

2. 第 2 段階: 弱オピオイド

我々の経験では, リン酸コデインを主軸とした第 2 段 階治療で癌疼痛管理が可能な症例は約 35\%にも及:36). 鎮咳薬としても用いられている薬物であり，才ピオイド 開始薬として患者の受け入れも容易であることが多い． さらに副作用の程度がモルヒネに比較して軽い6) ため， 臨床的には用いやすい薬物であるといえる . 問題点は徐 放薬がなく，一日の服薬回数が多いことである.リン酸 コデイン一日量として $100 \mathrm{mg}$ (分 4) 程度で開始し, レ スキューとして一回服用分を準備する. $300 \mathrm{mg}$ 力臨床的 有効限界であり7)，关の時点て鎮痛効果が不十分と考え られる例，あるいは投与初期の段階で全く鎮痛効果が得 られない例では躊踷なく第 3 段階治療薬へ移行する.

3. 第 3 段階: 強オピオイド

モルヒネ製剂の選択肢 (Table 1) カ増えたことで，患 者状態に適した薬斉選択が可能になった . 徐放製剂の欠 点であった血中濃度の立ち上がりの遅さに注目し，徐放 製剂でありながら速放成分をも配合させ，鎮痛効果の発 現が速いモルヒネ製剂も使用されるようになった 、一剂 で投与経路変更に対応できるモルヒネは，いまだオピオ イド鎮痛の中心的役割を果たしている．さらにモルヒネ のみではなく，オキシコドン，フェンタニル製剤も使用 できるようになったため，円滑なオピオイドローテー ションが可能になってきている .

(1)モルヒネ

モルヒネの鎮痛効果は, モルヒネ自体と肝蔵でグル 
Table 1 本邦で使用できる経口強オピオイド製剂の性質

\begin{tabular}{|c|c|c|c|c|c|}
\hline 薬物名 & 放出特性 & 商品名 & $\begin{array}{c}\text { 投与回数 } \\
\text { (回/日) }\end{array}$ & $\begin{array}{l}\begin{array}{l}\text { 最高血中濃度 } \\
\text { (時間) }\end{array}\end{array}$ & $\begin{array}{c}\text { 作用持続時間 } \\
\text { (時間) }\end{array}$ \\
\hline \multirow{4}{*}{ モルヒネ } & 速放性 & $\begin{array}{l}\text { モルヒネ末 } \\
\text { マルピー錠 } \\
\text { オプソ液 }\end{array}$ & $\begin{array}{c}5 \text { (就前 } 2 \text { 回分服用) } \\
\text { あるいは } 6\end{array}$ & $0.5 \square 1$ & 3凸 5 \\
\hline & \multirow{3}{*}{ 徐放性 } & $\begin{array}{l}\text { MS コンチン錠 } \\
\text { MS ツワイスロン } \\
\text { カプセル } \\
\text { モルペス細粒 }\end{array}$ & 2 & $2 \square 4$ & $8 \square 12$ \\
\hline & & $\begin{array}{c}\text { カディアンカプセル } \\
\text { カディアンスティック } \\
\text { ピーガード錠 }\end{array}$ & 1 & $6 \square 8$ & 24 \\
\hline & & パシーフカプセル & 1 & 1 & 24 \\
\hline \multirow{2}{*}{ オキシコドン } & 速放性 & オキノーム散 & 4 & $1 \square 2$ & $4 \square 6$ \\
\hline & 徐放性 & オキシコンチン錠 & 2 & З\ 5 & 12 \\
\hline
\end{tabular}

クロン酸抱合された活性代謝物である morphine-6-glucuronide (M-6-G) より発揮される. 主代謝産物である morphine-3-glucuronide (M-3-G) は $\mu$ 受容体には結合せ ず鎮痛活性はない8). 両代謝物とも腎より排泄されるた め, 腎機能障害患者では M-6-G 蓄積により鎮静，呼吸抑 制などが, M-3-G 蓄積によりミオクロースス, 痙攣など の副作用が発現しやすくなる ${ }^{9,10)}$.

(2)オキシコドン

徐放錠に続き, 速放散の発売により突出痛対策も同一 薬で行えるようになった .オキシコドンの $\mu$ 受容体に対 する親和性はモルヒネの 1/10-1/40 と弱いが, 肝初回通 過時にグルクロン酸抱合を受けにくいためにバイオアベ イラビリティーが高く, 経口投与による生体内利用率は 60-90\%とモルヒネの 20-30\%に比し高い. 产のため経口 投与時の鎮痛効果はモルヒネの 1.5 倍と大きい . 肝臓で 大部分が活性を有さないノルオキシコドンに代謝され る . 他の代謝産物であるオキシモルフォンは , オキシコ ドンの約 14 倍の鎮痛効果を有するが，血中に微量しか認 められない，代謝物は腎より排泄されるものの活性代謝 物がほとんどないため, モルヒネと異なり腎機能障害患 者でも使用しやすい9) . オキシコドンはモルヒネよりも 幻覚の発現頻度が低いため, モルヒネに起因するせん妄 にはオキシコドンへの変更で対処可能である ${ }^{11)}$. 副作用 発現率はモルヒネとほぼ同等と考えてよいが, 嘔気, 嘔 吐はやや少ない傾向にある ${ }^{12)}$.

(3)フェンタニル

フェンタニルは $\mu_{1}$ 受容体への親和性が高く，消化管輸 送を抑制する $\mu_{2}$ 受容体には作用しにくいため，モルヒネ に比し便秘を生じにくい13). 肝蔵代謝による主な代謝産 物は活性を持たないノルフェンタニルであり14)，腎機能 低下症例であっても代謝産物蓄積による副作用が少な
い.モルヒネの 160 倍の脂溶性により, 静脈内吸収後速 やかに脳脊髄内に移行し鎮痛効果を発揮する.フェンタ ニルの鎮痛効力は大きいものの，経口投与した場合には 腸管から血管内吸収直後の初回肝藏通過でほとんどが分 解されて効力を失うため内服薬としては機能しない，低 分子量で高脂溶性のため経皮吸収されやすく，兴の際は 肝藏での初回通過効果や消化管吸収による影響を受けな い. 貼付剤は徐放機構をもつ放出制御膜より一定量の割 合でフェンタニルを放出し $(2.5 \mathrm{mg}, 5 \mathrm{mg}, 7.5 \mathrm{mg}$ 製剂

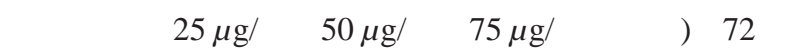
間安定した血中濃度を維持できる。ただし，体温上昇や 入浴，暖房による局所皮膚温上昇による血中濃度の増加 に留意せねばならない . 近日中にフェンタニルを含む基 剂が変更される，基阁性質上，含有されるフェンタニ ル量は多くなるが, 放出速度は現在のものと変わらず, さらに低用量の $12.5 \mu \mathrm{g} /$ 時製剂も使用可能となる.

(4)どの強オピオイドを用いるのがいいのか?

どの強オピオイドを用いても最終的にもたらされる鎮 痛効果に差は認められていないが，まずは速放薬を用い て投与量の増減を行うことが推奨されている．速放薬は 効果発現が速く，持続時間が短いため, 鎮痛の評価と投 与量の調整を迅速に遂行できるためである ${ }^{15)}$. しかし 各々の特徵を有した徐放薬の種類も豊富になり，臨床的 には徐放薬をべースに, 突出痛に対しては速放薬でレス キュー鎮痛を図ることが多いようである．モルヒネの開 始から鎮痛量へのタイトレーションに要する日数を速放 薬と徐放薬で比較した場合，両製剂とも約 2 日で完了で きると報告されており16)，徐放薬より治療開始する方法 の妥当性を裏付けている. 徐放薬の中でも作用発現の速 さに注目し選択すると, オキシコドンあるいはモルヒネ 速放性粒・徐放性粒配合カプセルが適している.レス 
キューには光れ速放製剤があるため, 至適鎮痛量へ のタイトレーションがしやすい .フェンタニル貼付薬は 作用発現に長時間を要するため即座に効果を判定でき ず，用量の切り替えが 3 日ごとになるためタイトレーシ ヨンに時間を要することより, 開始薬としては適切では ない . かつ光の間のレスキューとして現在フェンタニル の速放製剂がないため, 速放性モルヒネやオキシコドン を用いるしかなく, パッチ増量時の換算が煩雑である． しかし，経口摂取困難例，イレウスなどで消化管吸収障 害が疑われる症例ではモルヒネあるいはフェンタニルの 静脈内，皮下投与とともに貼付薬も適応となる. 経管栄 養チューブか溜置されている症例では細粒剂や散斉の注 入か薦められる . 高度の腎機能障害のある場合には才キ シコドンかフェンタニルが副作用回避の点で適してい る。

(5)第 2 段階からの切り替えの場合の投与量

Fig. 4 に示した投与量の等力価換算を目安として強才 ピオイドに変更する．たとえばコデインを $300 \mathrm{mg} /$ 日前 後で服用している症例では, 速放性モルヒネ $60 \mathrm{mg} /$ 日に

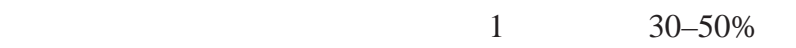
つ増量 (例 : $60 \rightarrow 90 \rightarrow 120 \rightarrow 180 \rightarrow 270 \rightarrow 360 \mathrm{mg} /$ 日) すれ ば, 安全で患者満足度の高い安定した鎮痛が得られ, 光 の後同量の徐放薬へ円滑に移行できる ${ }^{17)}$. 前項で述べた ようにフェンタニル貼付薬では迅速なタイトレーション が困難であることが指摘されている ${ }^{15)}$. 一方，280-360 $\mathrm{mg}$ /日のコデインから $2.5 \mathrm{mg}(0.6 \mathrm{mg} /$ 日) フェンタニル 貼付薬に切り替えることで安全に鎮痛できるとの報告 ${ }^{18)}$ もあるが，レスキュードーズの設定は十分にする必要が あるであろう .

(6)第 2 段階をスキップして強オピオイドから 開始する 場合の投与量

第 1 段階後すぐに強オピオイドを用いた治療を開始す る方が, 良好な鎮痛と高い患者満足度が得られるとの報 告 ${ }^{19)}$ がある. しかしコデインからの切り替え時と同樣 に，モルヒネ $60 \mathrm{mg} /$ 日あるいはフェンタニル貼付薬 2.5 $\mathrm{mg} /$ 日の投与量を用いた場合，鎮痛は得られるものの約 $70 \%$ で中等度から重度の副作用が発現し，約 40\%の症例 では投薬が中止されてしまう20).さらにコデインや他の 強オピオイドからフェンタニル貼付薬 $2.5 \mathrm{mg} /$ 日に変更 する症例より, 同薬を最初から使用する症例で副作用発 現率が高い21).つまり第2 段階をスキップして, 強オピ オイドから治療開始する場合には初期用量を低く設定す る必要がある．たとえばモルヒネ一日量 $15 \mathrm{mg}$ 程度より 開始しタイトレーションを行った場合, 副作用にて途中 離脱する例は $10 \%$ と低率であり, 鎮痛量は開始 4 週後で 平均 $45 \mathrm{mg}$ /日と低用量で維持できる22). オキシコドンの 場合も同樣で $10 \mathrm{mg} /$ 日より開始することか推奨される ${ }^{23}$. フェンタニル貼付薬の場合は最低規格が $2.5 \mathrm{mg} /$ 日のた

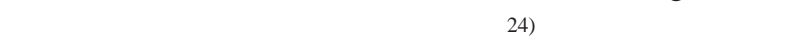

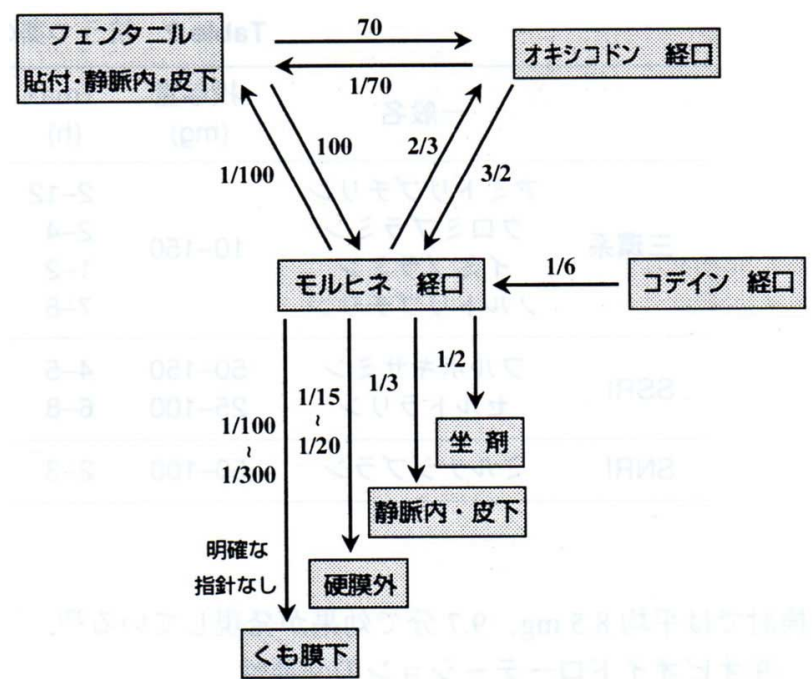

Fig. 4 オピオイドの鎮痛力価の目安 相対力価を目安とし, 疼痛, 副作用の程度を観察の上, 投与 量を決定する .

ダーム ${ }^{\mathrm{TM}}$ のような踈水性テープを皮膚に貼り，フェンタ ニル貼付薬の半分を兴のテープ上に，残り半分を直接皮 膚に貼付する . パッチの接地面積により吸収速度が規定 されることを利用した方法であるが, 実際の放出速度に ついて科学的証明は成されていない，前述したように低 用量の規格が増えればこの問題は解決する .

(7)突出痛に対するレスキュードーズ

突出痛 (breakthrough pain) は癌疼痛患者の約 65\% で認 められ25)，通常の痛みよりも強度のため日常生活動作に 多大に影響する．レスキュードーズには定時投与されて いるオピオイドと同成分の速放薬を同一経路で投与する ことか望ましい，モルヒネの場合一日投与量の $1 / 6$ を， オキシコドンの場合は $1 / 4$ を一回量とする . 速放薬の場 合には服用 30 分て鎮痛効果が得られ, 60 分後には光の 効果判定ができる．弚のため 1 時間間隔で疼痛を評価 し，鎮痛不十分時にはさらに使用できるように設定して おく.ー日のレスキュードーズの合計を翌日の徐放薬量 に加算していくと，早期に個々の至適鎮痛量に到達でき る.フェンタニル貼付薬に対応する速放薬は口腔粘膜吸 収薬として現在臨床試験中であるが, モルヒネ, オキシ コドン速放薬よりも作用発現が速く, 10 分程度て効果発 現する点で突出痛対策に期待されている26). 現状ではレ スキュー薬として速放性モルヒネを用い，一日換算量の $1 / 6$ を一回分とする .

(8)モルヒネ間歇的静脈内投与による一日投与量の決定 法

痛みが強度で早期の鎮痛が必要な場合，モルヒネを $2 \mathrm{mg}$ ずつ 2 分間隔で静脈内投与し, 痛みが軽減し始め た時点 (無痛ではない) の総投与量の 6 倍 (モルヒネの単 回静脈内投与の効果時間を 4 時間と仮定して) を一日静 脈内投与量 , 兴の 2-3 倍量を経口投与量とする . 海外の 
Table 2 抗うつ薬の投与法と薬理学的特徵

\begin{tabular}{|c|c|c|c|c|c|c|c|c|}
\hline & 一般名 & $\begin{array}{c}\text { 投与量 } \\
\text { (mg) }\end{array}$ & $\begin{array}{c}\mathrm{T} \max \\
(\mathrm{h})\end{array}$ & $\begin{array}{c}\text { T1/2 } \\
\text { (h) }\end{array}$ & $\begin{array}{c}\text { 抗コリン } \\
\text { 作用 }\end{array}$ & $\begin{array}{l}\text { 鎮静 } \\
\text { 作用 }\end{array}$ & $\begin{array}{l}\text { 起立性 } \\
\text { 低血圧 }\end{array}$ & $\begin{array}{c}\text { 心臓への } \\
\text { 影響 }\end{array}$ \\
\hline \multirow{4}{*}{ 三環系 } & \multirow{4}{*}{$\begin{array}{c}\text { アミトリプチリン } \\
\text { クロミプラミン } \\
\text { イミプラミン } \\
\text { ノルトリプチリン }\end{array}$} & \multirow{4}{*}{$10 \square 150$} & $2 \square 12$ & $9 \square 25$ & ++++ & +++ & +++ & +++ \\
\hline & & & $2 \square 4$ & $19 \square 37$ & +++ & ++ & +++ & +++ \\
\hline & & & $1 \square 2$ & 8[ 16 & ++ & ++ & +++ & +++ \\
\hline & & & $7 \square 8$ & $18 \square 35$ & + & + & + & ++ \\
\hline \multirow{2}{*}{ SSRI } & フルボキサミン & $50 \square 150$ & 4! 5 & $9[14$ & ૫ & प & प & प \\
\hline & セルトラリン & $25 \square 100$ & $6 \square 8$ & 24 & प & प & प & प \\
\hline SNRI & ミルナシプラン & $50 \square 100$ & $2 \square 3$ & 8 & — & ] & — & ] \\
\hline
\end{tabular}

検討では平均 $8.5 \mathrm{mg}, 9.7$ 分で効果が発現している ${ }^{27)}$.

9)オピオイドローテーションの必要性

強オピオイドには天井効果がないにもかかわらず，投 与量を急速に増量しても十分な鎮痛が得られない場合 や，コントロールできない重度の副作用により増量が困 難である場合には他の才ピオイドに変更する必要があ る.これをオピオイドローテーションあるいはオピオイ ドスイッチングと呼び, モルヒネにて治療している患者 の 10-30\%は前述の理由により経過中必要とされる 28 30). 変更時には薬斉間の鎮痛用量換算 (Fig. 4) が必要とな る . 鎮痛は得られていたものの副作用が原因でローテー ションする際，あるいは投与量が比較的少量の際には， 単純に等換算量の他のオピオイドに切り替えることが可 能である . 注意すべきはかなり高用量のオピオイドで管 理されていた症例で，ある種の耐性による鎮痛効果の減 少が疑われる場合に, 交差耐性のない他斉に等鎮痛用量 で即時に変更してしまうと，結果的に過剩投与となり副 作用か顕著に発現する可能性があることである．乥こで 一時に変更するのではなく，段階的に他剂に変更してい く方法が薦められる. 当然のことながら変更に合わせた レスキュードラッグ，ドーズも設定しておく必要があ る.さらには, 全身状態の悪化等に伴うモルヒネの経口 投与から経直腸投与や静脈内投与等への投与経路変更時 にも用量換算は重要である (Fig. 4) .

半減期の長いオピオイドに変更する場合には, 变更後 の徐放薬の血中濃度が十分に上昇してくるまで, 変更前 の薬剤を一時継続しなければならない，たとえばフェン タニル貼付薬に変更する場合には, 前薬がモルヒネやオ キシコドンの 1 日 2 回服用の徐放薬あるいはモルヒネ坐 薬であれば一回量を貼付とともに投与する . 速放薬であ れば貼付時と光の後もう一回分を服用させる. 一日一回 服用のモルヒネ徐放薬からの切り替えであれば, モルヒ ネ内服 12 時間後に貼付する. 逆にフェンタニルから経口 投与切り替え時には, パッチを剥がしても皮膚内には フェンタニルが 12 時間程度残存するため, 剥離より 12 時間後に徐放薬を投与開始し, 坐薬, 速放薬であれば 16 時間後に開始する．

\section{V. 鎮痛補助薬を上手に使う}

癌の痛みは癌組織が侵害受容器を刺激して生ずる侵害 受容性疼痛機序が主であり, 通常オピオイドに反応しや すい．しかし骨転移に起因した体動時痛の場合にはオピ オイドだけの治療では難渋することが多い，さらに癌の 脊髄や末梢神経への浸潤あるいは圧迫，化学療法に伴う ニューロパチーなどの神経障害性疼痛が混在することも 稀ではない，乥の場合才ピオイド治療に抵抗しやすいた め, 鎮痛補助薬を適宜併用する必要がある .

(1)抗うつ薬

神経障害性疼痛のうち，しびれ，絞めつけられるなど の鈍い持続性の痛み, 軽い触刺激により痛みが誘発され るアロディニアに有効である．下行性疼痛抑制系の賦活 化，オピオイド受容体を介する抗侵害作用，NMDA 受 容体抑制作用，損傷神経の神経腫上に発現した $\alpha$ アドレ ナリン受容体遮断作用，局所麻酔薬樣作用等の機序によ り鎮痛効果をもたらす.三環系抗うつ薬であるアミトリ プチリン , ノルトリプチリンの使用率 , 有効率が高い31). アミトリプチリンは眠気の頻度が高く，逆にノルトリプ チリンでは眠気は強くない (Table 2) .よって, 痛みによ り睡眠障害が生じているケースではアミトリプチリン， 眠気により activities of daily living (ADL) を障害したく ない例ではノルトリプチリンを選択する．副作用の少な い点でセロトニン・ノルアドレナリン再取り込み阻害薬 (SNRI) や選択的セロトニン再取り込み阻害薬 (SSRI) か ら開始することもある .

\section{(2)抗痤攣薬}

間歇的で刺すような鋭い痛み，電撃痛，放散痛に効果 がある . カルバマゼピン , フェニトイン , バルプロ酸ナ トリウム , クロナゼパムなどが用いられるが，欧米では ガバペンチンの使用率が高い31) . 神経障害性疼痛を合併 する癌疼痛の場合，才ピオイドとガバペンチンの併用で 鎮痛効果はさらに高まる ${ }^{32}$. 本邦では保険適応がないも のの，われわれの検討では 200-2400 mg/日量で神経障害 性疼痛に有効であった ${ }^{33)}$. またオピオイドの長期使用に より生ずるミオクロースス治療にも有効と報告されてい 
る ${ }^{34)}$. 同じ GABA 誘導体であるプレガバリンは疼痛治療 薬として現在臨床試験段階にあり，光の効果か期待され ている.

\section{(3)ステロイド}

神経障害性疼痛, 骨性の痛み, 倦怠感, 食欲不振に有 効である . 漸減しやすいプレドニゾロンを用いることが 多い，一日量として $30 \mathrm{mg}$ 程度から開始し，3 日ごとに $10 \mathrm{mg}$ ずつ減量し，5-10 mg/日て濰持する ${ }^{35)}$. 投与量が $30 \mathrm{mg} /$ 日を超えると副作用発生率か増加するため, 漫然 と高用量で維持しないことが肝要である . また長期間の 服用時には消化性潰瘍の発生に十分に留意し, 胃粘膜保 護薬を併用すべきであるとともに，谷の間の NSAIDs 同 時投与は避けるべきであろう .

(4)ビスホスホネート

癌の骨転移痛，骨折予防として用いられる。破骨細胞 機能，増殖を抑制し，アポトーシスを生じさせる.当初 は多発性骨髄腫, 肺癌や乳癌などの溶骨性骨転移に用い られたが, 造骨性のものでも骨の代謝回転は速く，溶骨 性変化も共存することから前立腺癌などの造骨性転移巣 でも有効性が確認されている ${ }^{36)}$. 重大な副作用として顎 骨壊死が報告されているが，ビスホスホネート投与中の 歯科治療との関連性が疑われており，投与中は抜歯など の侵襲的歯科治療は回避すべきである ${ }^{37)}$.ゾレドロン酸 水和物 $(4 \mathrm{mg}$ を生食 $100 \mathrm{ml}$ に溶解し 15 分以上かけて点 滴) やパミドロン酸二ナトリウム (30-45 mg を生食 500 $\mathrm{m} l$ に溶解し 4 時間以上かけて点滴) などを 4 週間隔で投 与する .

(5)ケタミン

ケタミンは麻薬指定されたため鎮痛補助薬の範疇には ないが，才ピオイドへの耐性を解除する ${ }^{38)}$ など補助薬と しての役割も有している．またモルヒネは内藏痛には高 い効果を発揮するものの体性痛には効果か溺いため，モ ルヒネ抵抗性の疼痛に主治療薬として持続静脈内投与 (3-20 mg/時) することもある ${ }^{39)}$. 幻覚や悪夢などの精神 症状を予防するためドロペリドールや抗不安薬を併用す る。

\section{VI．神経ブロックの有用性}

特殊な手技を要するため，WHO ラダーのように誰で も施行できるわけではないが, 癌疼痛のうち初期の段階 で神経破壞薬を用いた神経ブロックを行うことて鎮痛効 果が速やかに得られ, 弚の結果 QOL が向上し, オピオ イド使用量や副作用を軽減することができる . 上腹部，

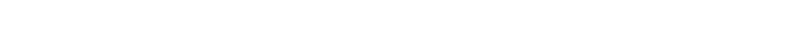
ク，下腸間膜動脈神経叢ブロック，上下腹神経叢ブロッ ク (Fig. 5) が, 胸部痛, 会陰部痛にはくも膜下ブロック が適応となる．また癌患者では活動制限に伴う筋筋膜性 疼痛を頚部，肩，腰背部に合併している場合が少なくな い. 弚の際は局所麻酔薬やステロイドを用いたトリガー

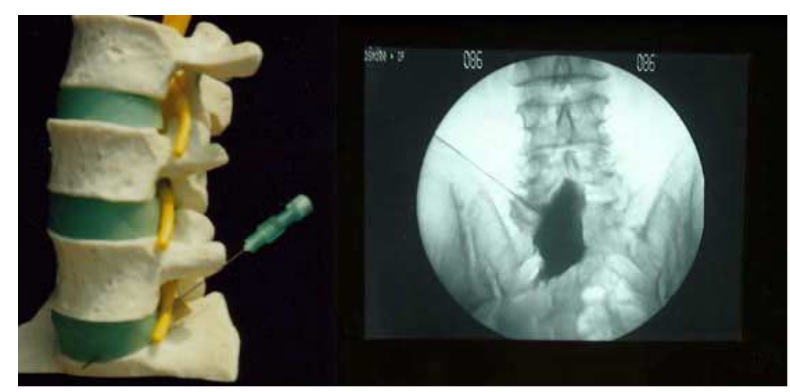

Fig. 5 上下腹神経叢ブロックの針刺入経路と造影所見

ポイント注射を繰り返し行うことも有用である.当科の データによると，WHO 第 3 段階薬使用率は内藏神経ブ ロック未施行群の $70 \%$ に較ベ , ブロック施行群では $17 \%$

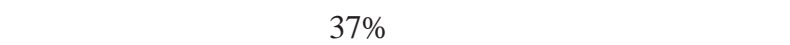
た 、つまりオピオイド使用前に神経ブロックの適応につ いて評価する価値がある .

おわりに

癌疼痛治療法の現状と進歩について, 薬物療法を中心 に，実際に臨床応用できるよう概説したつもりである． 治療時には各薬物の副作用と光の対策に関する知識も必 須であるが，この点は成書を参照していただきたい．

\section{文献}

1) Pharo GH, Zhou L. Controlling cancer pain with pharmacotherapy. J Am Osteopath Assoc 2007; 107 (suppl 7): ES 22-32.

2) Zech DFJ, Grond S, Lynch J, et al. Validation of world health organization guidelines for cancer pain relief: a 10-year prospective study. Pain 1995; 63: 65-76.

3) Meuser T, Pietruck C, Radbruch L, et al. Symptoms during cancer pain treatment following WHO-guidelines: a longitudinal follow-up study of symptom prevalence, severity and etiology. Pain 2001; 93: 247-257.

4) 中込昌子，小川節郎，佐伯 茂, 他. 癌疼痛に対する消 炎鎮痛薬による治療経験 .ペインクリニック , 1993; 14 849-852.

5) Farooqui M, Li Y, Rogers T, et al. COX-2 inhibitor celecoxib prevents chronic morphine-induced promotion of angiogenesis, tumour growth, metastasis and mortality, without compromising analgesia. Br J Cancer 2007; 97: 1523-1531.

6) 水野 薰, 小川節郎, 斎藤英夫, 他 . 癌疼痛に対するリ ン酸コデインの鎮痛効果の検討 .ペインクリニック , 1992; 13: 191-194.

7) 中込昌子，小川節郎，佐伯 茂, 他 .リン酸コデインの 効果的な投与法の検討 .ペインクリニック , 1993; 14: 533-536.

8) Penson RT, Joel SP, Bakhshi K, et al. Randomized placebocontrolled trial of the activity of the morphine glucuronides. Clin pharmacol Ther 2000; 68: 667-676.

9) Hanks GW, Reid C. Contribution to variability in response to opioids. Support CareCancer 2005; 13: 145-152.

10) Bartlett SE, Dodd PR, Smith MT. Pharmacology of morphine and morphine-3-glucuronide at opioid, excitatory amino acid, GABA and glycine binding sites. Pharmacol Toxicol 1994; 75 : 73-81. 
11) Maddocks I, Somogyi A, Abbott F, et al. Attenuation of morphine-induced delirium in palliative care by substitution with infusion of oxycodone. J Pain Symptom Manage 1996; 12: 182-189.

12) Reid CM, Martin RM, Sterne JAC, et al. Oxycodone for cancer-related pain. Meta-analysis of randomized controlled trials. Arch Intern Med 2006; 166: 837-843.

13) 鈴木 勉. 医療用麻薬の薬理学的特徵 . LiSA 2005; 12: 3036.

14) Labroo RB, Paine MF, Thummel KE, et al. Fentanyl metabolism by human hepatic and intestinal cytochrome P450 3A4: implications for interindividual variability in disposition, efficacy, and drug interactions. Drug Metab Dispos 1997; 25: 1072-1080.

15) Hanks GW, de Conno F, Cherny N, et al. Morphine and alternative opioids in cancer pain: the EAPC recommendations. $\mathrm{Br} \mathrm{J}$ Cancer 2001; 84: 587-593.

16) Klepstad P, Kaasa S, Jystad A, et al. Immediate- or sustainedrelease morphine for dose finding during start of morphine to cancer patients: a randomized, double-blind trial. Pain 2003; 101: 193-198.

17) Klepstad P, Kaasa S, Skauge M, et al. Pain intensity and side effects during titration of morphine to cancer patients using a fixed schedule dose escalation. Acta Anaesthesiol Scand 2000; 44: 656-664.

18) Mystakidou K, Befon S, Kouskouni E, et al. From codeine to transdermal fentanyl for cancer pain control: a safety and efficacy clinical trial. Anticancer Res 2001; 21: 2225-2230.

19) Marinangeli F, Ciccozzi A, Leonardis M, et al. Use of strong opioids in advanced cancer pain: a randomized trial. J Pain Symptom Manage 2004; 27: 409-416.

20) van Seventer R, Smit JM, Schipper RM, et al. Comparison of TTS-fentanyl with sustained-release oral morphine in the treatment of patients not using opioids for mild-to-moderate pain. Cur Med Res Opin 2003; 19: 457-469.

21) Tawfik MO, Bryuzgin V, Kourteva G, et al. Use of transdermal fentanyl without prior opioid stabilization in patients with cancer pain. Cur Med Res Opin 2004; 20: 259-267.

22) Mercadante S, Porzio G, Ferrera P, et al. Low morphine doses in opioid-naïve cancer patients with pain. J Pain Symptom Manage 2006; 31: 242-247.

23) Koizumi W, Toma H, Watanabe K, et al. Efficacy and tolerability of cancer pain management with controlled-release oxycodone tablets in opioid-naïve cancer pain patients, starting with 5 mg tablets. Jpn J Clin Oncol 2004; 34: 608-614.

24) Peng YR, Sun WZ. Mini-dose titration of the transdermal fentanil patch - a novel approach by adjusting the area of ab- sorption. J Pain Symptom Manage 2005; 30: 7-8.

25) Caraceni A, Martini C, Zecca E, et al. Breakthrough pain characteristics and syndromes in patients with cancer pain. An international survey. Palliat Med 2004; 18: 177-183

26) Zeppetella G. Opioids for cancer breakthrough pain: a pilot study reporting patient assessment of time to meaningful pain relief. J Pain Symptom Manage 2008 (in press).

27) Mercadante $S$, Villari $P$, Ferrera $P$, et al. Rapid titration with intravenous morphine for severe cancer pain and immediate oral conversion. Cancer 2002; 95: 203-208.

28) Indelicato RA, Portenoy RK. Opioid rotation in the management of refractory cancer pain. J Clin Oncol 2002; 20: 348352.

29) Mercadante S, Bruera E. Opioid switching: a systematic and critical review. Cancer Treat Rev 2006; 32: 304-315.

30) Cherney N, Ripamonti C, Pereira J, et al. Strategies to manage the adverse effects of oral morphine: an evidence-based report. J Clin Oncol 2001; 19: 2542-2554.

31) Berger A, Dukes E, Mercadante S, et al. Use of antiepileptics and tricyclic antidepressants in cancer patients with neuropathic pain. Eur J cancer Care (Engl) 2006; 15: 138-145.

32) Keskinbora K, Pekel AF, Aydinli I. Gabapentin and an opioid combination versus opioid alone for the management of neuropathic cancer pain: a randomized open trial. J Pain Symptom Manage 2007: 34: 183-189.

33) 渡部愛子, 小林真己子, 石川貴洋子, 他 . 各種神経障害 性疼痛に対するガバペンチンの有用性について．日本ペ インクリニック学会誌, (in press).

34) Mercadante S, Villari P, Fulfaro F: Gabapentin for opioid-related myoclonus in cancer patients. Support Care Cancer 2001; 9: 205-206.

35) 鈴木孝浩, 間瀬 清, 佐伯 茂, 他 . 癌疼痛に対する鎮 痛補助薬プレドニゾロンの適応と効果 . 日本ペインクリ ニック学会誌, 1995; 2: 14-17.

36) Gralow J, Tripathy D. Managing matastatic bone pain: the role of bisphosphonates. J Pain Symptom Manage 2007; 33: 462472.

37) Marx RE, Sawatari Y, Fortin M, et al. Bisphosphonate-induced exposed bone (osteonecrosis/osteopetrosis) of the jaws: risk factors, recognition, prevention, and treatment. J Oral Maxillofac Surg 2005; 63: 1567-1575.

38) Bell RF. Low-dose subcutaneous ketamine infusion and morphine tolerance. Pain 1999; 83: 101-103.

39）金丸哲也，佐伯 茂，勝又德一，他 . 種々の鎮痛法に抵 抗した癌終末期疼痛症例に対するケタミン持続点滴法の 効果 . 麻酔，1990; 39: 1368-1371. 